\title{
MAPPING OF HAZARDS TO KARST GROUNDWATER ON THE VELIKA PLANINA PLATEAU (SLOVENIA)
}

\section{KARTIRANJE ONESNAŽEVALCEV KRAŠKE PODTALNICE NA VELIKI PLANINI (SLOVENIJA)}

GREGOR KOVAČIČ́ ${ }^{1}$, NATAŠA RAVBAR ${ }^{2}$

\footnotetext{
${ }^{1}$ University of Primorska, Faculty of Humanities Koper, Department of Geography, Glagoljaška 8, SI-6000 Koper, Slovenia, e-mail: gregor.kovacic@fhs-kp.si

${ }^{2}$ Karst Research Institute, ZRC SAZU, Titov trg 2, SI-6230 Postojna, Slovenia,

e-mail: natasa.ravbar@zrc-sazu.si
}

Prejeto / received: 15. 11. 2004 


\section{Gregor Kovačič \& Nataša Ravbar: Mapping of hazards to karst groundwater on the Velika planina plateau}

The present paper presents the hazard mapping of groundwater on the Velika planina alpine karst plateau. There are no permanent residents on the plateau. Nevertheless, some serious hazards to the quality of the respective karst springs are arising from sports, tourist and farming activities. Some pollution has been already recorded in springs, showing the shortcomings of drinking water management also in uninhabited alpine karst areas, which are ordinarily very favourable for water protection.

Key words: alpine karst, karst hydrology, hazard mapping, contamination of karst aquifers, protection of karst aquifers.

Izvleček

UDK: $551.44: 556.388$

$556.388: 551.44$

\section{Gregor Kovačič \& Nataša Ravbar: Kartiranje onesnaževalcev kraške podtalnice na Veliki planini}

Prispevek obravnava kartiranje onesnaževalcev podtalnice na alpski kraški planoti Velika planina. Kljub temu, da na planoti ni stalne poselitve, je kakovost vode $\mathrm{v}$ izvirih pod planoto ogrožena zaradi športne, turistične in živinorejske aktivnosti na planoti. V izvirih so že zabeležili onesnaženje, kar kaže na pomanjkljivosti upravljanja s pitno vodo tudi na neposeljenih območjih alpskega krasa, ki so sicer z vidika varovanja zelo primerna za zaščito.

Ključne besede: alpski kras, kraška hidrologija, kartiranje onesnaževalcev, onesnaževanje kraških vodonosnikov, varstvo kraških vodonosnikov. 


\section{INTRODUCTION}

Karst aquifers are particularly susceptible to pollution. Due to a thin protective soil cover and common absence of other protective overlaying layers, such as subsoil (non-lithified material below the topsoil, for example Quaternary deposits) and non-karst rocks, to rapid recharge of the infiltrating water into the underground and its fast distribution over large distances and to high flow velocities and short residence time in case of Slovene karst aquifers, a self-cleaning capacity of the karst systems is very low. Consequently, the remediation and neutralizing of the infiltrating contaminants in the karst network is negligible and pollution can be transported over large distances without effective attenuation of contaminant concentration. Therefore serious pollution problems may result from different human impacts. According to the water-protection policy, hazard mapping and assessment provide a useful conceptual framework within which all human activities in the catchment areas of the respective wells and karst springs tapped for the water supply may be evaluated in holistic terms (Drew \& Hötzl 1999).

In many European karst regions and also in Slovenia the concept of hazard mapping is coming to the fore in order to protect more and more valuable groundwater resources (Špes et. al 2002, Zwahlen 2004). For this purpose the intensity, extent and duration of an imposed stress need to be quantified.

The present paper is a study and a review of potential and actual hazards to the groundwater on the Velika planina plateau. Many useful and valuable data were gathered in previous investigations (Novak \& Bizjak 1989, Novak 1992, 1994, 1994/95, Kopač 1991, Palčič 2002, Kovačič \& Ravbar 2005). During the systematic examinations in 2003 and 2004 potential and actual hazards on the Velika planina plateau were recorded and mapped. It is possible that some of the hazards remained unrecorded. All mapped hazards were analyzed by computer using GIS.

Initially, the geographical position, geological, geomorphological and hydrogeological characteristics of the Velika planina plateau are explained and shown on the simplified maps. Later there follows the explanation of actual and potential hazards to karst groundwater. Potential and actual hazards are also listed and shown on the map which also demonstrates geomorphologic data of surface formations that are liable to filter seepage water or to favour concentrated recharge (Williams 1983).

\section{GEOGRAPHICAL POSITION AND NATURAL CHARACTERISTICS OF THE VELIKA PLANINA PLATEAU}

The Velika planina plateau is found on the eastern part of the Kamniške-Savinjske Alps massif (Fig. 1). It is a high alpine karst plateau at an altitude between 1,300 to 1,600 m. It is mainly inclined towards the east.

The karst aquifer is surrounded by the valley of Kamniška Bela on the northwest, Kamniška Bistrica on the west, Črna on the south, Volovjek on the southeast, the valley of Brložnica with the spring of Lučnica on the east and the valley of Lučka Bela on the northeast. On the northern side, Velika planina is connected with the eastern side of the Kamniške-Savinjske Alps across the mountain Rzenik $(1833 \mathrm{~m})$. Except for the eastern side of the plateau, slopes on all margins are rather steep.

The studied area, which forms a geographical unit named Velika planina, encompasses three mountain meadows with the associated pastures. These are Velika, Mala and Gojška planina (planina 
= mountain meadow), which extend from Šimnovec on the west to Marjanine njive on the east. Meadows stretch from Kisovec in the south and pass over to the forest ranges and further towards planina Konjščica and Dol to the north. The studied area covers $36.5 \mathrm{~km}^{2}$ (Fig. 2).

\section{Geological and geomorphological characteristics}

In the geotectonic sense the studied area belongs to the Southern Alps. Velika planina is a big shallow syncline of the Savinja thrust sheet, composed mainly of Middle and Upper Triassic carbonates and pushed southward on Tertiary layers of the Tuhinj syncline (Premru 1982). In the northern part Anisian dolomite and limestone emerge, which extend to Rzenik (Novak \& Bizjak 1989). Along the northern edge of the syncline Anisian clastites, marl and breccia appear as well. On the outmost northern edge of the plateau, between mountain pastures Konjščica and Rzenik there is a patch of Oligocene layers (Premru 1982). The southern part of the studied area is mainly covered by gray and black dolomite; some limestone, clay and marl layers are also present. Gojška and Mala planina are built of alternating layers of dark gray limestone, marly limestones and schists. The limestone contains up to 84 per cent of carbonate constituent. It is mixed with clay particles, which are softer and therefore susceptible to weathering. Marly schists contain up to 47 per cent of carbonate (Premru 1982).

The Velika planina plateau is bordered by faults on all sides. On the southern fringe stretch layers of metamorphic rocks. Strong tectonics in the past have above all caused creation of tuff, kaolin and quartz keratophyre (Premru 1982). Rubble and scree appear on the slopes.

The karstification processes in the studied area began in the Lower Pliocene and were interrupted during the Pleistocene period, when the relief was also transformed by glacial processes (Premru 1982). Intensive karstification was replaced by strong mechanical weathering. Remains of the glacial processes (glacial deposits and specific rocky relief) are found all over the Kamniške-Savinjske Alps. Several expressive dish-shaped and funnel-shaped dolines, collapse dolines and dry valleys are found on the Velika planina plateau. Velika and Mala Vetrnica are among the biggest collapse dolines (Kunaver 1953). They are situated in the middle of the plateau. Two bigger dry valleys occur on the plateau. Dol is situated in the northern part and Kisovec is in the southern part of the plateau. Dolines and dry valleys cover about 3 per cent of the studied area (Fig. 5).

Other characteristic karst features also appear on the plateau, such as snow kettles, solution pans and karren. According to the Cadastre of caves (2003) there have been 16 caves registered in the studied area. The average length of these caves is 120 metres; however more than 80 per cent of them are shorter than one hundred metres. The average depth of the caves is 26 metres; but more than half are not more than ten metres in depth. The longest and the deepest cave is Jama v Kofcah, 1090 meters long and 103 meters deep.

Among all the registered caves only eight are dry and six are ice and snow caves. Three caves are horizontal and six are shafts. Tomažičeva zijalka, Jama v Kofcah, Sandijeva jama and Brezno v Jerohi I are caves that contain flowing water (Kregar 1986).

\section{Hydrological characteristics}

There are no surface running waters present on the plateau, only a few smaller springs appear which are commonly captured and used for the individual water supply of nearby mountain lodges and holiday huts. In the margins of the Velika planina plateau several springs occur, some of these also 
are captured for the water supply of small areas. In Fig. 2 only the important springs are shown.

The karst waters mainly outflow through the slope rubble that covers the respective karst springs. On the slopes above regular springs, ravines are present which are active during high waters and intensive precipitation events. Spring caves do not appear.

Tracings of the groundwater flow have shown that the autochthonous precipitation water from the surface of the Velika planina plateau percolates directly into the karst aquifer and runs mostly towards the Lučnica karst spring (Fig. 2). Important outflows are also in the area of Dolski potok, Konjski potok, springs Krivčevo, Šunce, Brložnica and some smaller springs in the Črna valley (Novak \& Bizjak 1989, Novak 1994).

Tracing of the underground water in Brezno $v$ Jerohi has proved the underground water connection with sources Lučnica, Lučka Bela, Žegnani studenec, Sedem studencev and Krivčevo. Tracers injected into the swallow hole situated near the mountain hut Dom črnuških planincev appeared in the springs Lučnica, Konjski potok, Šunce, Krivčevo and Dolski potok. Colouring of the Hotel Šimnovec sewage has shown connection with the captured spring above Kraljev hrib and with Lučnica spring. Tracer injected into Brezno v Črni has appeared in Šunce and Krivčevo springs (Novak 1994/95).

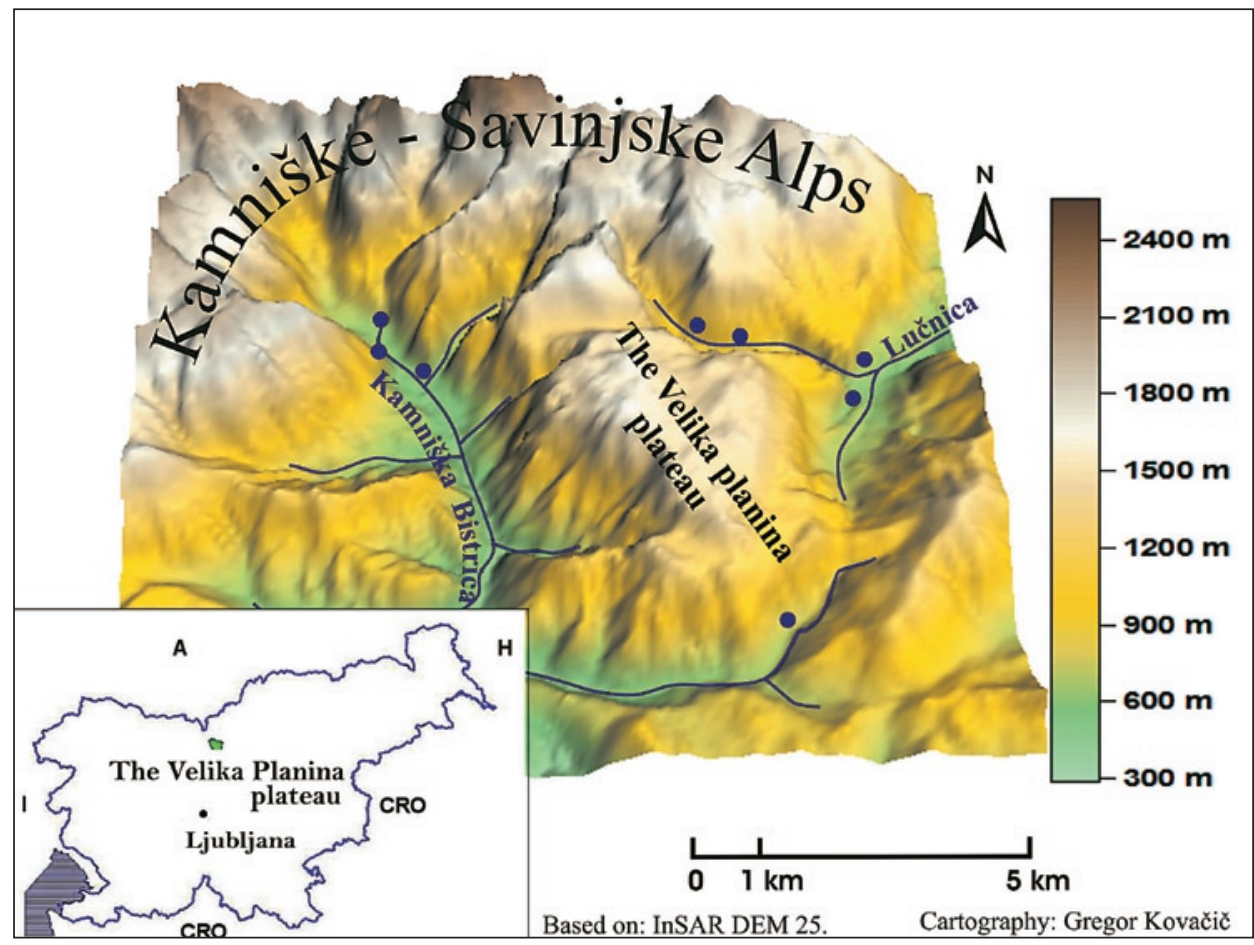

Fig. 1: Geographical position of the Velika planina plateau. 


\section{DESCRIPTION OF HAZARDS}

\section{Pasturing and tourism}

Mountain pastures on the Velika planina plateau were already exploited in prehistory, which is proved by archeological finds from the Bronze Age (axe) and from the Middle Ages (ceramics)

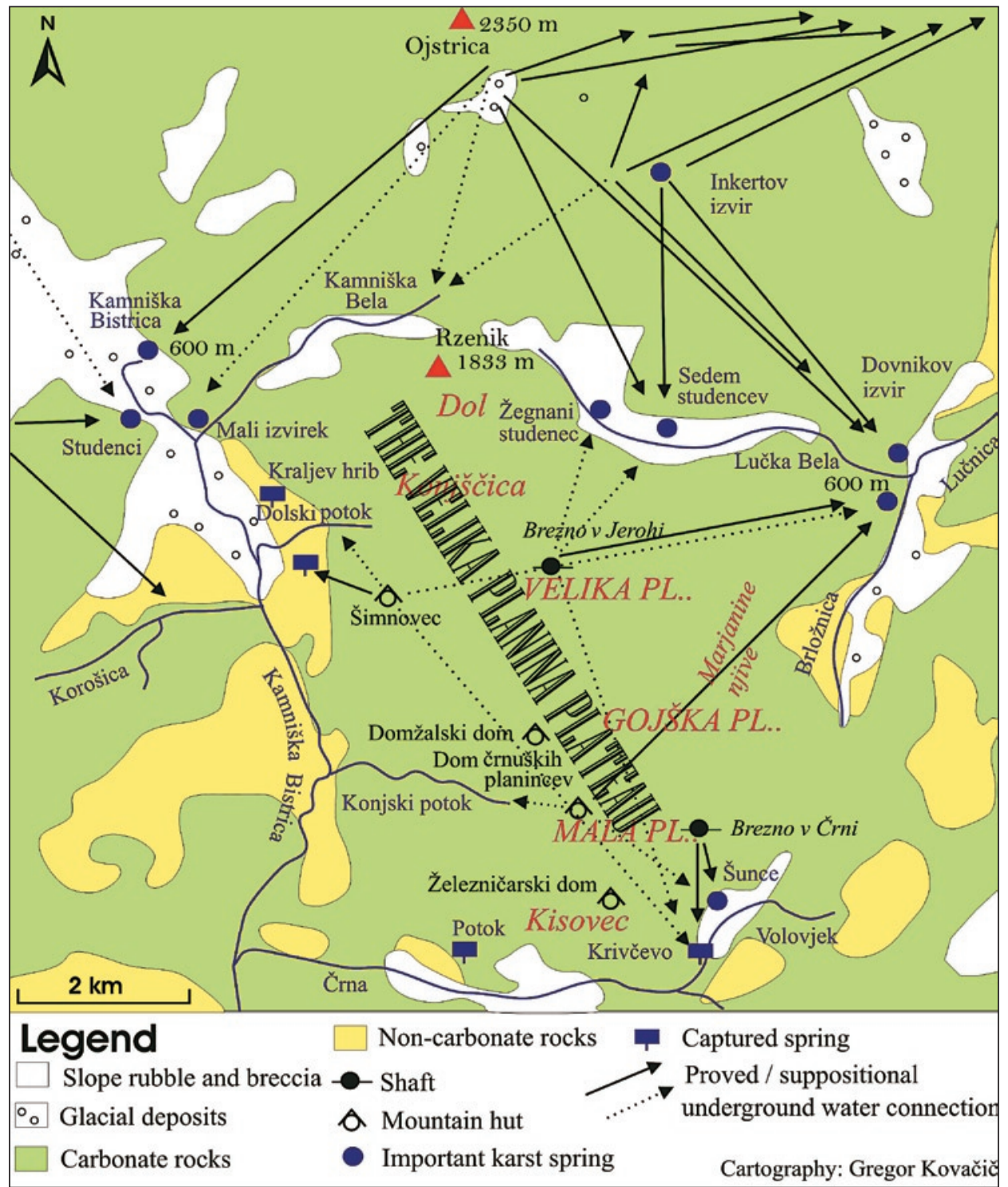

Fig. 2: Simplified geological map of the Velika planina plateau with proved and supposed groundwater connections (after Premru 1982, Novak 1994/95). 
(Cevc 1993). In later periods the mountain pastures were used only for seasonal pasturing, because several natural conditions (altitude, climate) did not allow permanent rural activity.

Today the Velika planina plateau does not have permanent residents. There are around 170 holiday huts, some mountain lodging houses and some pastoral houses still used by herdsmen. The most important economic occupation in the warm season is stockbreeding, but above all tourism occurs all the year round. Settlements of holiday huts are restricted to the northwestern part of the plateau (around Šimnovec, Purman, Gradišče and Na jamah), where the surface is not so convenient for pasturing. However, on all mountain pastures of the Velika planina plateau pasturing is strongly associated with tourism and most of the pastoral houses have been changed into mountain lodging houses.

The Velika planina plateau is very easily accessible. It lies in the vicinity of the most densely urbanized parts of Slovenia (in the hinterland of big cities like Ljubljana, Kamnik, Kranj and Celje) therefore there are many visitors especially during weekends and holidays.

The plateau is accessible from different directions. There are many tracks, footpaths and lately more and more tractor roads have appeared. In the second half of the $20^{\text {th }}$ Century more mountain huts and a cableway with load capacity 400 people per hour and some chair lifts were built. With new infrastructure, tourist development accelerated. There are 244 beds registered altogether, but the actual number is even bigger while there is a possibility of cottage rental.

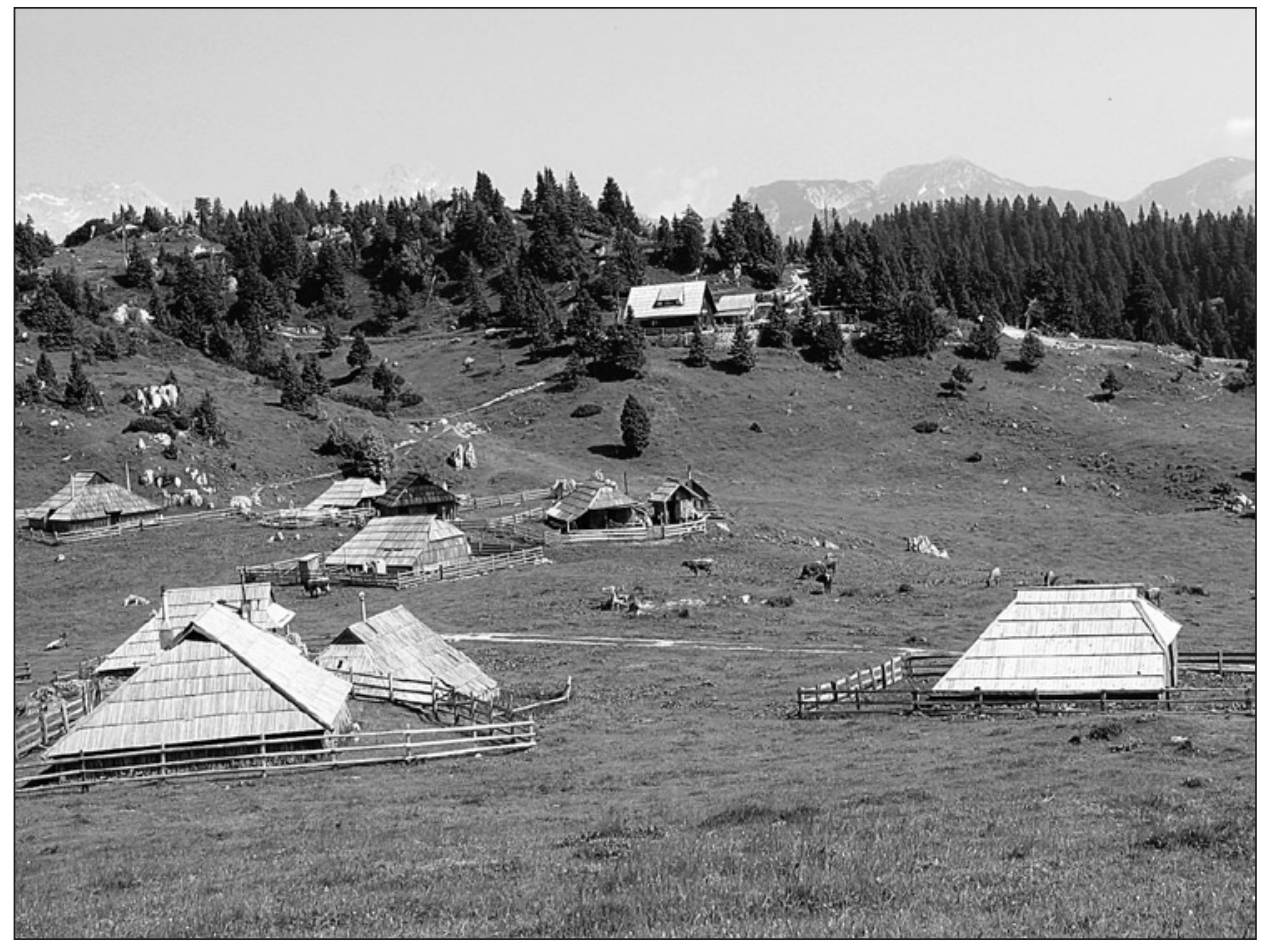

Fig. 3: On the Velika planina plateau pasturing is strongly associated with tourism and most of the pastoral houses have been changed into mountain lodging houses. 
The one-day guests mostly visit Velika planina, only during the summer and winter months also stationary tourism is also present. In 2001 almost 40,000 people were carried by the cableway (one forth of the total being in August), and at least double this number come to the plateau on foot. Of the plans in the 1970s to modify the Velika planina plateau into a ski center, only the construction of ski lifts has been realized. Today there are about 40 hectares of ski slopes and seven kilometers of ski routes (Kopač 1991).

\section{Point hazards predominate}

On the Velika planina plateau point hazards prevail. Danger to the quality of groundwater comes above all from water percolating from cesspits. Holiday settlements, mountain lodging houses and pastoral houses do not have suitable systems for wastewater drainage. Untreated and uncontrolled release of wastewater is left to infiltrate into the underground. Among the 291 buildings registered on the plateau, only the biggest mountain hut Domžalski dom regularly sends away waste waters to the small water treatment plant.

Faecal waters flow into permeable cesspits and consequently unclean water percolates directly into the subsurface. Many of the pastoral houses also have their own manure heaps, which are not regulated according to water-protection standards. Manure usually lies on the surface at the back of the pastoral houses (Fig. 4). There is a slight possibility that the leaking fluids from the manure contaminate underground water, specially in the cases of concentrated surface runoff towards the points of fast infiltration such as dolines and shafts. The upper limit of cattle numbers on each

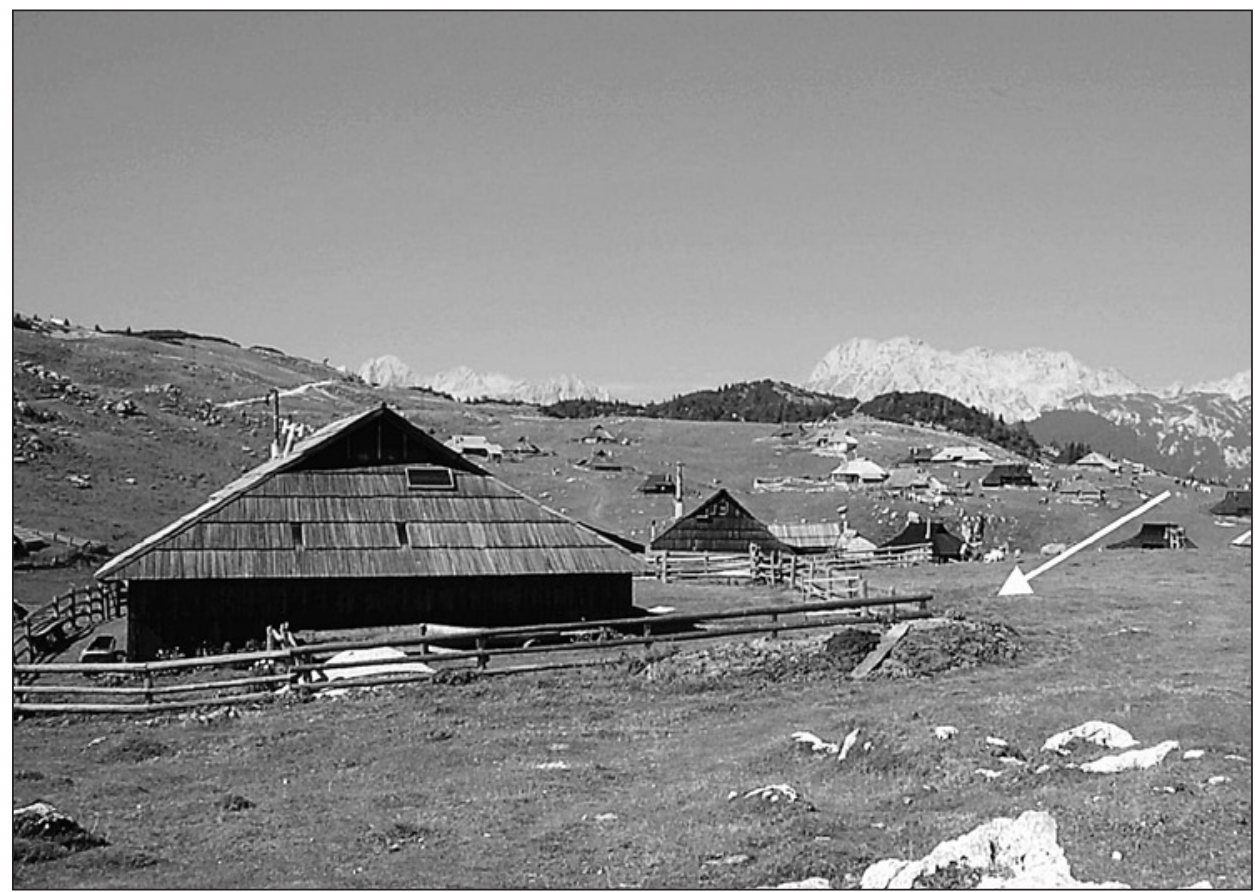

Fig. 4: Many of the pastoral houses have their own manure heaps. 
Gregor Kovačič \& Nataša Ravbar: Mapping of hazards to karst groundwater on the Velika planina plateau

\begin{tabular}{|c|c|c|c|c|c|c|c|}
\hline \multirow{2}{*}{$\begin{array}{l}\text { Name of a } \\
\text { meadow }\end{array}$} & \multirow{2}{*}{$\begin{array}{c}\text { Total surface of a } \\
\text { meadow (in ha) }\end{array}$} & \multicolumn{2}{|c|}{$\begin{array}{l}\text { Surface } \\
\text { of pasture }\end{array}$} & \multicolumn{2}{|c|}{$\begin{array}{l}\text { Surface } \\
\text { of forest }\end{array}$} & \multirow{2}{*}{$\begin{array}{l}\text { Upper limit } \\
\text { of } \\
\text { cattle } \\
\text { number }\end{array}$} & \multirow{2}{*}{$\begin{array}{l}\text { Actual } \\
\text { number } \\
\text { of cattle }\end{array}$} \\
\hline & & (in ha) & (in \%) & (in ha) & (in \%) & & \\
\hline Velika planina & 554 & 300 & 60 & 250 & 45,1 & 487 & 334 \\
\hline Mala planina & 201 & 118 & 58,7 & 83 & 41,3 & 191 & 143 \\
\hline Gojška planina & 209 & 118 & 56,5 & 91 & 43,5 & 318 & 176 \\
\hline
\end{tabular}

Fig. 5: The table shows total surface of meadows on the Velika planina plateau, surface of pasture and forest, the upper limit of cattle number and the actual number of cattle in 2001 (source: Babnik 2002)

mountain meadow is by tradition limited, but the actual number of cattle on the meadows per year is much lower (Fig. 5). In the authors' opinion, cattle density does not pose a threat to the quality of karst groundwater.

There are several illegal waste-disposal dumps. Only on the Velika planina mountain meadow there were 40 garbage dumps registered in 2002 and one third of them were larger than $10 \mathrm{~m}^{3}$. Their overall volume amounted to $250 \mathrm{~m}^{3}$ of waste material. The dumps are most frequent in the vicinity

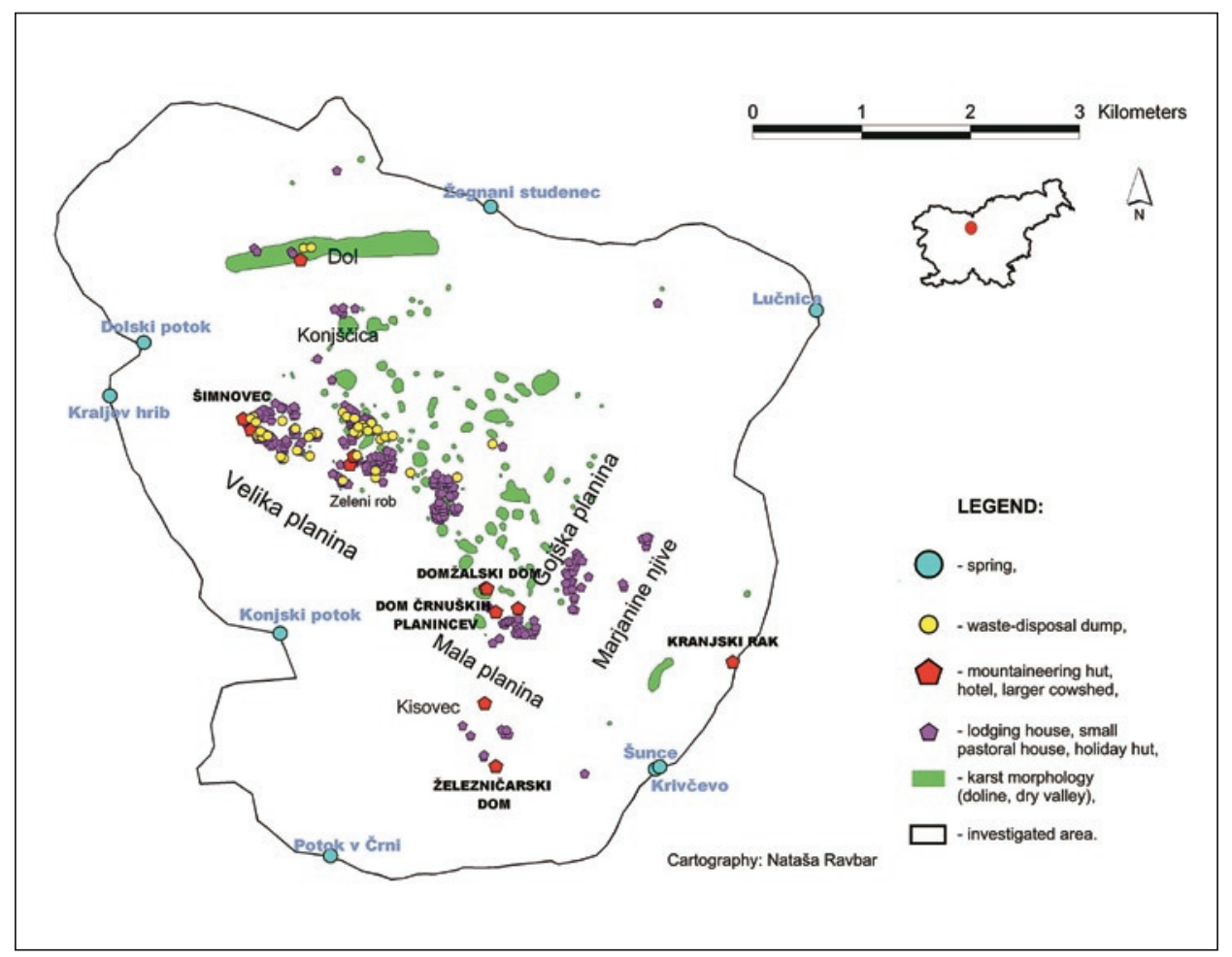

Fig. 6: Hazard map of the Velika planina plateau. 
of the tourist settlements, where the holiday huts are owned by different companies and where the frequency of the visitors is the highest. Northward and southward of Šimnovec, private holiday huts prevail, so illegal dumps are less frequent. In Tiha dolina, where the ski slopes are, two dumps were found. Fewest dumps are present in the pastoral settlements (Palčič 2002). There are also two garbage dumps in the Dol dry valley. On the dumps domestic, building and furniture waste material prevail, while dangerous waste material is present only in very limited amounts.

The diesel generating set that drives the ski lifts presents a potential threat to the groundwater in case of accident. Since the natural snowfall is commonly insufficient and artificial snow is not created, the ski lifts mostly stand idle. Skiing activity is therefore not very extensive. The authors believe that it does not present danger to the quality of groundwater. For that reason ski slopes and cableway are not described as hazards and so are not presented on the hazard map.

\section{DISCUSSION AND CONCLUSION}

As karst aquifers are very dynamic systems and monitoring points of groundwater pollution are few, the detection of actual hazards to the quality of groundwater is very difficult. Mapping of the potential and actual sources of pollution is a valuable practical tool for further land-use planning and groundwater protection but many of them cannot be yet confirmed (Kovačič \& Ravbar 2005).

In order to determine if human activities in a catchment area pose a threat to the quality of groundwater, analyses performed at springs and wells of different depths in karst aquifers are possible. Springs, which represent the output points for the karst conduits, can be effective monitoring points of pollution in karst aquifers, since they may discharge the integrated flow from their catchment area.

Chemical and microbiological analyses performed in some springs under the Velika planina plateau have shown a slight impact of human activities on the plateau to the quality of karst water. Signs of organic contamination have already been recorded in the respective karst springs, among which there are also some captured for water supply. The concentrations did not exceed the maximum permissible values for drinking water. Although bacteriological analyses of water have been acceptable, there was increased consumption of $\mathrm{KMnO}_{4}$ in the Lučnica and Konjska springs that is an index of organic pollution. Higher concentrations of $\mathrm{PO}_{4}$ and $\mathrm{NO}_{3}$ in the springs Lučnica, Krivčevo, Dolski potok, Kamniška Bistrica and Konjska indicate domestic sewages or products of decomposition (Novak 1992, 1994/95).

There are no permanent residents on the plateau, but the springs are endangered by sports, tourist and farming activities. Mountain lodging houses and holiday huts have built-in cesspits, which are not properly constructed, and around many of the buildings illegal waste-disposal dumps appear. Actual and potential threats to the quality of karst water are faecal and domestic wastewaters, a growing consumption of chemical cleaning agents and detergents, and waste-disposal dumps. There is also a possibility of water pollution coming from cattle breeding activities. Increase of tourist capacities could mean strong enlargement of the wastewaters amount.

Concentrations of contaminants recorded in the springs of the Velika planina karst plateau were low and water is still suitable for drinking even without pretreatment.

The alpine and high dinaric karst regions are among all karst areas in Slovenia the most convenient for water protection. The Velika planina plateau is a good example, showing that even in 
non-industrialized and uninhabited karst areas some serious actual and potential hazards can be found, which constitute a threat to drinking water. Nitrate contents that have been noticed in some springs are excellent indicators of pollution related to cattle farming and domestic waste (Novak 1992, 1994/95).

In the terms of sustainable water management, the development of massive tourism on the plateau would not be suitable. In order to preserve the quality of groundwater the remediation of illegal waste-disposal dumps is needed and the construction of impermeable cesspits in all buildings. Lastly an effective inspection over the potential hazards is needed and also the education of visitors and owners of the huts and houses of the significance of sustainable water management on the plateau.

\section{REFERENCES}

Babnik, A., 2002: Razvojne možnosti Velike planine v okviru predvidenega Karavanško-KamniškoSavinjskega regijskega parka.- Diplomsko delo. Oddelek za geografijo Filozofske fakultete Univerze v Ljubljani. 95 p., Ljubljana.

Cadastre of caves, Speleological association of Slovenia and Karst research institute ZRC SAZU, Ljubljana, 2003. (unpublished)

Cevc, T., 1993: Velika planina : življenje, delo in izročilo pastirjev.- Inštitut za slovensko narodopisje ZRC SAZU, 112 p., Ljubljana.

Drew, D. \& H. Hötzl, 1999: Karst Hydrology and Human Activities.- International Contributions to Hydrogeology, International Association of Hydrologists, A. A. Balkema, 322 p., Rotterdam.

Kopač, M., 1991: Velika planina. Valorizacija krajinskega območja za potrebe razvoja.- Katedra za krajinsko arhitekturo Biotehniške fakultete, 34 p., Ljubljana.

Kovačič, G. \& N. Ravbar, 2005: A review of the potential and actual sources of pollution to groundwater in selected karst areas in Slovenia.- Natural Hazards and Earth Systems Science. Special issue, 5, 225-233.

Kregar, V., 1986: O raziskavah vodnih razmer v jamah na Veliki planini.- Naše jame, 28, 63-64, Ljubljana.

Kunaver, P., 1953: Kraški pojavi v Kamniških planinah.- Planinski vestnik, 53, 261-270, Ljubljana.

Novak, D. \& M. Bizjak, 1989: Hidrogeološke raziskave za sanacijo zajetij v občini Kamnik.- Poročilo, Arhiv Geološkega zavoda Slovenije, 15 p., Ljubljana.

Novak, D., 1992: Z gore teče (tudi) umazanija.- Planinski vestnik, 92, 16-17, Ljubljana.

Novak, D., 1994: Oskrba s pitno vodo v občini Kamnik.- Geografski vestnik, 66, 145-160, Ljubljana.

Novak, D., 1994/95: Underground waters in Kamnik and Savinja Alps.- Geologija, 37, 38, 415-435, Ljubljana.

Palčič, M., 2002: Pokrajinski vidiki sanacije odlagališč odpadkov na Veliki planini.- Diplomsko delo, Oddelek za geografijo Filozofske fakultete Univerze v Ljubljani, 37 p., Ljubljana.

Premru, U., 1982: Osnovna geološka karta Jugoslavije. Tolmač za list Ljubljana.- Zvezni geološki zavod Beograd, 75 p., Beograd.

Špes, M., Cigale, D., Lampič, B., Natek, K., Plut, D. \& A. Smrekar, 2002: Študija ranljivosti 
okolja. (Metodologija in aplikacija).- Geographica Slovenica 35, 1-2. Založba ZRC, 150 p., Ljubljana.

Williams, P. W., 1983: The role of the subcutaneous zone in karst hydrology.- Journal of hydrology, 61, 45-67, Amsterdam.

Zwahlen, F., 2004: Vulnerability and Risk Mapping for the Protection of Carbonate (Karstic) Aquifers. Final report COST action 620.- European Commission, Directorate-General for Research, 297 p., Brüssel, Luxemburg.

\section{KARTIRANJE ONESNAŽEVALCEV KRAŠKE PODTALNICE NA VELIKI PLANINI}

\section{Povzetek}

V Sloveniji so kraški vodonosniki zaradi omejenih samočistilnih sposobnosti izredno občutljivi na onesnaženje. Zaščitna plast prsti in vegetacije je na zakraselih območjih zelo tanka, malo je tudi nesprijetih sedimentov in nekraških kamnin v pokrovu. Tako onesnaževala ob prenikanju nimajo nobenega naravnega filtra, da bi se kemično, biološko in fizikalno očistila. V kraških vodonosnikih so procesi samoočiščevanja pogosto manj učinkoviti tudi zaradi hitre infiltracije padavin v podzemlje in zato, ker se snovi hitro prenesejo daleč stran od točke vnosa.

Skladno s konceptom vodovarstvene politike predstavlja ocenjevanje in kartiranje potencialnih in dejanskih onesnaževalcev podtalnice na kraških območjih koristno orodje. Omogoča celovito oceno ogroženosti in obremenjenosti zajetih kraških izvirov in vrtin, ki izhaja iz različnih človekovih dejavnosti v pripadajočih napajalnih zaledjih.

Velika planina je visokogorska kraška planota na vzhodnem robu Kamniško-Savinjskih Alp. Obsega tri večje gorske planine s pašniki. To so Velika, Mala in Gojška planina (Sl. 1). Geografsko je Velika planina relativno dobro omejen kraški vodonosnik, ki ga obkrožajo doline Kamniške Bele, Kamniške Bistrice, Črne, Brložnice, Lučke Bele in Volovjeka. V geotektonskem smislu pripada Velika planina prostoru Južnih Alp. Zgrajena je pretežno iz apnencev in dolomitov triasne starosti (Premru 1982) (Sl. 2). Vmes se pojavljajo tudi plasti laporjev, glinavcev in breč.

Zakrasevanje Velike planine se je začelo v spodnjem pliocenu, v času pleistocena pa je bilo območje podvrženo delovanju ledeniških procesov. Planota je prepredena z vrtačami različnih oblik, dimenzij in nastanka, suhimi dolinami, jamami in brezni. Med registriranimi jamami je tudi nekaj takih, kjer naletimo na vodni tok.

Na planoti ni površinsko tekočih voda, pojavlja se nekaj manjših izvirov, ki so običajno zajeti za vodooskrbo bližnjih gorskih in počitniških hiš. Podzemne vode s planote napajajo izvire na njenem robu. Nekateri med njimi so tudi zajeti za vodooskrbo manjših območij (Novak 1994/95). Infiltrirana padavinska voda večinoma polni kraški izvir Lučnice, s sledenji pa so bile dokazane povezave tudi z izviri v dolini Lučke Bele (Žegnani studenec, Sedem studencev), z izviri v dolini Volovjeka in Črne (Potok, Šunce in Krivčevo) ter z izviri v dolini Kamniške Bistrice (Kraljev hrib, Konjski potok, Dolski potok) (Sl. 2).

Na Veliki planini ni stalne poselitve, vendar so kraški izviri ogroženi zaradi športnih, turističnih in živinorejskih aktivnosti na planoti. Kemične analize vode v izvirih pod Veliko planino so poka- 
zale rahlo organsko onesnaženje kraške podtalnice, vendar koncentracije niso presegale najvišjih dovoljenih vrednosti za pitno vodo (Novak 1994/95).

Prevladujejo točkovni potencialni in dejanski onesnaževalci podzemne vode (Sl. 5). Največjo nevarnost za kakovost kraške podtalnice predstavljajo greznice, ki niso zgrajene v skladu z vodovarstvenimi zahtevami, zato odpadne vode največkrat neovirano pronicajo v podzemlje. Potencialno nevarnost predstavljajo tudi odprta gnojišča, saj izcedne vode neprečiščene odtekajo v notranjost kraškega vodonosnika, vendar pa lahko do resnega onesnaženja pride samo v primeru koncentriranja odtoka izcednih vod skozi točke hitre infiltracije, denimo vrtače in brezna. Po mnenju avtorjev gostota živine ne predstavlja resne grožnje za kakovost podtalnice. Veliko bolj so nevarna številna divja odlagališča odpadkov, katerih skupna prostornina je ocenjena na $250 \mathrm{~m}^{3}$. Prevladujejo gospodinjski in gradbeni odpadki.

Alpska in visoko dinarska kraška območja so za varovanje voda zelo primerna, saj so praviloma neposeljena. Primer Velike planine pa kaže, da lahko naletimo na resne dejanske in potencialne onesnaževalce kakovostne kraške podtalnice tudi na neposeljenih in neindustrializiranih kraških območjih. V smislu sonaravnega gospodarjenja z vodo, razvoj množičnega turizma na Veliki planini ne bi bil primeren. Če želimo ohraniti kakovostno pitno vodo tudi v prihodnje, je potrebno sanirati divja odlagališča odpadkov ter urediti greznice v vseh stavbah skladno z vodovarstvenimi zahtevami.

Vendar pa se moramo zavedati, da obstoječih problemov v zvezi z onesnaževanjem kraške podtalnice ne bomo rešili zgolj z meritvami in prepovedmi tehnične narave. Predvsem je potrebno spremeniti človekov odnos do narave in naravnih virov ter izobraževati ljudi o pomenu varovanja pitne vode. 